burning, tree-felling or grazing and there was considerable danger that certain birds adapted to the forest habitat, already rare, might become extinct. The Island is now one of the few remaining large areas of native forest in New Zealand and one bird, the stitchbird (Notiomystis cincta), is believed to be unique to the area. The Bulletin provides an admirable account of the various elements of the environment-geology, physiography, soils, fauna and flora together with an introductory section on the Maori occupation. Hauturu is a dissected volcanic cone, probably Mid-Pleistocene in age, rising to a height of $2,370 \mathrm{ft}$. Andesites and andesitic breccias are the predominant rock types although there are small areas of Holocene (Flandrian) deposition. The vegetation shows a vertical zonation modified by the destruction that took place before 1896. These areas are rapidly reverting to Kauri forest (and other broad leaf communities) through transition phases of heptospermum forest. The forest areas provide the habitat for many native (and some introduced) birds. The main disturbing factor is the presence of cats although every attempt is being made to eliminate these. Their effect on the bird population is, however, considered to be slight. Some species have been introduced to the Island, one of which, the North Island Kiwi, seems to have been successful. There are also several curiosities including the tuatara and Spenceriella gigantea, a $4 \frac{1}{2}-\mathrm{ft}$. long earthworm. The Bulletin, naturally, is mainly of local interest but it should have a wider appeal to geomorphologists and ecologists for the accounts of the dissected volcano and the vegetation pattern.

\section{Cosmology and Meteorology in the U.S.S.R.}

A NUMBER of articles dealing with the various aspects of recent cosmic flights was published during 1961 in the Soviet popular scientific journal Priroda. These include: $8,7,15,16 ; 9,9,24,54,75 ; 10,23$, $32 ; 11,9$. According to V. P. Petrov and A. A. Sochivko (Priroda, 7, 25; 1961), future development of cosmic flights may help to map out the cosmic background responsible for the changes in terrestrial weather. Special space stations, regularly distributed around the Earth and to be called 'geophysical sputniks', will carry special equipment suitable for such a task. The recorded data will be transmitted continuously to the terrestrial receiving stations. In a short article, B. I. Vronsky (Priroda, 9, 90; 1961) describes the five meteorites (locality marked on a sketch map) which have recently been found in the north-east Siberian territory. They are: (1) Susuman, 1937; (2) Mal'dyak, 1939; (3) Burgavli, 1941; (4) Yudoma, 1946; (5) El'ga, 1959. The last-mentioned meteorite, El'ga, found deep down in auriferous gravels (see also Nature, 187, 648; 1960), consisted essentially of nickel-iron with 10-15 per dispersed stony chondrules, the main constituents of which are alkali feldspar and clinopyroxene, with small amounts of glass and maskelinite. The metallic part, the chemical analysis of which is given, is composed essentially of kamacite and tænite. On February 18, 1961, Soviet and visiting astronomers had the chance of observing a full eclipse of the Sun, and this event gave the physicists the opportunity of trying a new method of insemination of clouds by granular 'dry ice'. These experiments, carried out in the Crimea, were very successful. The details of the process of artificial cloud dispersion are described by V. V. Vyal'tsev (Priroda, 11, 79; 1961.
Hydrology and Water-power in the U.S.S.R.

A PROJECT of linking some of the rivers flowing into the Arctic Ocean with the River Volga is briefly outlined by G. L. Sarukhanov (Priroda, 7, 53; 1961) and also by $\mathrm{N}$. S. Buyakovsky and M. I. L'vovich (Priroda, 6, 58; 1961). The main necessity is the steadily lowering level of the Caspian Sea, producing a crisis in navigation and fisheries. It is suggested that the upper reaches of the Rivers Pechora and Vychigda (a tributary of Northern Dwina) be dammed so as to transfer 40 milliards cubic feet of water annually into the Rivers Kama and Volga. This would make possible the formation of large water reservoirs and improved river navigation. Ya. A. Mazover and V. K. Saveliev give a summary account of the prospects for the wider utilization of water and fossil fuel powers in the U.S.S.R. (Priroda, $10,49 ; 1961)$. The important feature in the problems of energetics in the European part of the U.S.S.R. is that consumption is above reserves, while in the Asiatic part consumption is well below reserves. Gigantic hydroelectric installations, like those of the Angara-Yenisey, will in time enormously increase the output of energy. Transport of fuel and trans. mission of energy from regions of potentially low consumption to regions of high consumption may solve this discrepancy. Local development of industries will also tend to restore the balance of energetics. In any event, it is anticipated that there will be a considerable flow of energy westwards from central Asia and western Siberia.

\section{Non-Pressure Methods of applying Wood Preser- vatives}

ReCORD No. 31 of Forest Products Research, issued by the Department of Scientific and Industrial Research, includes concise descriptions of applying preservatives to timber by brushing, spraying, dipping, steeping, and the hot and cold open-tank and diffusion processes (Record No. 31. Non-pressure Methods of applying Wood Preservatives. By J. Bryan and D. F. Purslow. Pp. iv $+14+8$ plates. London: H.M.S.O., 1961. 2s. 6d. net). Immersion treatments ensure more complete contact between the wood and preservative, and thus can be more effective than other non-pressure methods. Their effectiveness depends to a certain extent on the period of immersion, but better results can be obtained by the well-known open-tank process. The plates illustrate the varying degrees of penetration obtained and two examples of an open-tank. Simple and readily understood graphs show rates of absorption for different preservatives by steeping and by double heating open-tank process. This useful booklet will bo appreciated by those requiring an understanding and a practical guide to the subject.

\section{Resinification of Knots in Radiata Pine}

Is New Zealand it has been found that during the kiln drying of radiata pine, the checking of intergrown knots is much worse in those which have a low content of resin and are large. Therefore, in order to try to improve the quality of kiln-dried radiata pine so far as knots affect it, two practical possibilities are considered in Forestry Research Notes, No. 28, issued by the New Zealand Forest Service, namely, the increased resinification of knots and artificial pruning treatments (The Resinification of Knots in Radiata Pine. By J. Maddern Harris. Pp. 10. Wellington: Government Printer, 1961). Ex- 